University of Nebraska - Lincoln

DigitalCommons@University of Nebraska - Lincoln

2000

\title{
Interleukin-1 polymorphisms associated with increased risk of gastric cancer
}

\author{
Emad M. El-Omar \\ National Cancer Institute \\ Mary Carrington \\ National Institutes of Health, carringm@mail.nih.gov \\ Wong-Ho Chow \\ National Cancer Institute \\ Kenneth E. L. McColl \\ Western Infirmary \\ Jay H. Bream \\ National Cancer Institute
}

See next page for additional authors

Follow this and additional works at: https://digitalcommons.unl.edu/publichealthresources

Part of the Public Health Commons

El-Omar, Emad M.; Carrington, Mary; Chow, Wong-Ho; McColl, Kenneth E. L.; Bream, Jay H.; Young, Howard A.; Herrera, Jesus; Lissowska, Jolanta; Yuan, Chiu-Chin; Rothman, Nathaniel; Lanyon, George; Martin, Maureen; Fraumeni, Joseph F. Jr.; and Rabkin, Charles S., "Interleukin-1 polymorphisms associated with increased risk of gastric cancer" (2000). Public Health Resources. 132.

https://digitalcommons.unl.edu/publichealthresources/132

This Article is brought to you for free and open access by the Public Health Resources at DigitalCommons@University of Nebraska - Lincoln. It has been accepted for inclusion in Public Health Resources by an authorized administrator of DigitalCommons@University of Nebraska - Lincoln. 


\section{Authors}

Emad M. El-Omar, Mary Carrington, Wong-Ho Chow, Kenneth E. L. McColl, Jay H. Bream, Howard A. Young, Jesus Herrera, Jolanta Lissowska, Chiu-Chin Yuan, Nathaniel Rothman, George Lanyon, Maureen Martin, Joseph F. Fraumeni Jr., and Charles S. Rabkin 


\section{Interleukin-1 polymorphisms associated with increased risk of gastric cancer}

Emad M. El-Omar ${ }^{\star} \dagger$, Mary Carrington $\ddagger$, Wong-Ho Chow ${ }^{\star}$, Kenneth E. L. McColl\$, Jay H. Bream\|, Howard A. Young\|, Jesus Herrerał, Jolanta Lissowskag, Chiu-Chin Yuan $\neq$, Nathaniel Rothman*, George Lanyon $\$$, Maureen Martin $\neq$, Joseph F. Fraumeni Jr* \& Charles S. Rabkin*

*Division of Cancer Epidemiology and Genetics, National Cancer Institute, Bethesda, Maryland, USA

$\dagger$ Department of Medicine and Therapeutics, Aberdeen University, Aberdeen, UK $\ddagger$ Intramural Research Support Program, Science Applications International Corporation Frederick, National Cancer Institute-Frederick Cancer Research and Development Centre, Maryland, USA

$\$$ Department of Medicine and Therapeutics, Western Infirmary, Glasgow, UK $\|$ Division of Basic Sciences, National Cancer Institute, Frederick Cancer Research and Development Centre, Maryland, USA

I Division of Cancer Epidemiology and Prevention, Cancer Centre and

M. Sklodowska-Curie Institute of Oncology, Warsaw, Poland

Helicobacter pylori infection is associated with a variety of clinical outcomes including gastric cancer and duodenal ulcer disease ${ }^{1}$. The reasons for this variation are not clear, but the gastric physiological response is influenced by the severity and anatomical distribution of gastritis induced by $H$. pylori. Thus, individuals 
with gastritis predominantly localized to the antrum retain normal (or even high) acid secretion ${ }^{2}$, whereas individuals with extensive corpus gastritis develop hypochlorhydria and gastric atrophy ${ }^{3}$, which are presumptive precursors of gastric cancer ${ }^{4}$. Here we report that interleukin-1 gene cluster polymorphisms suspected of enhancing production of interleukin-1-beta are associated with an increased risk of both hypochlorhydria induced by $\mathrm{H}$. pylori and gastric cancer. Two of these polymorphism are in near-complete linkage disequilibrium and one is a TATA-box polymorphism that markedly affects DNA-protein interactions in vitro. The association with disease may be explained by the biological properties of interleukin-1-beta, which is an important pro-inflammatory cytokine ${ }^{5}$ and a powerful inhibitor of gastric acid secretion ${ }^{6,7}$. Host genetic factors that affect interleukin-1-beta may determine why some individuals infected with $H$. pylori develop gastric cancer while others do not.

$H$. pylori infects half of the world's population and has been implicated in the pathogenesis of gastric cancer ${ }^{1}$, the second-most common malignancy worldwide ${ }^{8}$. The mechanism of $H$. pyloriinduced carcinogenesis is not clear. The infection almost always causes inflammation of the gastric mucosa, the distribution and severity of which varies widely and affects the clinical outcome. Gastritis that is confined to the antral region is associated with excessive acid production and a high risk of duodenal ulcer disease ${ }^{2}$. In contrast, gastritis involving the acid-secreting corpus region leads to hypochlorhydria, progressive gastric atrophy ${ }^{3}$ and an increased risk of gastric cancer ${ }^{4,9}$. These pre-cancerous changes are unfavourable to $H$. pylori growth and some gastric cancers arise long after the infection has disappeared. Duodenal ulceration and gastric cancer seem to be mutually exclusive outcomes of $H$. pylori infection that cannot be explained by differences in bacterial virulence factors alone, as virulent strains seem to be equally associated with both conditions ${ }^{10,11}$. An alternative explanation is that host genetic factors (in conjunction with bacterial and/or environmental factors) determine the immune and inflammatory responses to $H$. pylori infection. A critical factor in $H$. pylori-induced gastric carcinogenesis is gastric acid secretion, which both influences and is influenced by H. pylori-induced gastritis. If inflammation of the corpus mucosa is severe, acid secretion is inhibited and eventually lost through the destruction of gastric glands ${ }^{3}$. Furthermore, pharmacological inhibition of acid secretion leads to the re-distribution of $H$. pyloriinduced gastritis with a reduced intensity of antral inflammation

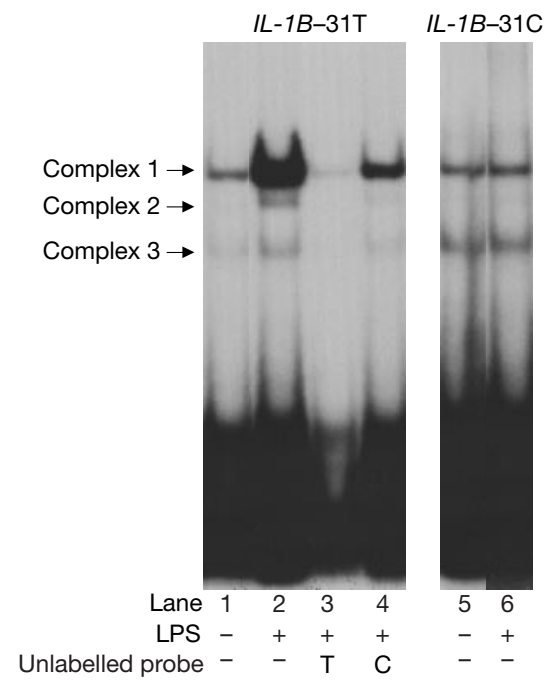

Figure 1 Differential binding patterns between the T- and C-bearing alleles of the $I L-1 B$ promoter. Nuclear extracts from fresh human monocytes stimulated for 30 min with lipopolysaccharide (LPS) (+) show evidence of induction of DNA-protein complexes 1 and 2 on the $I L-1 B-31 T$ oligonucleotide. Complex 3 and free probe were equivalent across all lanes. Cold competition with a 100-fold excess of unlabelled probe (T) blocked the formation of complex 1 (lane 3), whereas cross-competition with unlabelled IL-1B - 31C (C) only partially blocked complex 1 (lane 4). Results were similar with monocyte extracts from three different donors.

and an increased intensity in the corpus, and may progress to gastric atrophy in the long term ${ }^{12}$. Endogenous factors that suppress acid secretion could also contribute to corpus gastritis and atrophy.

The interleukin-1 ( $I L-1)$ gene cluster on chromosome $2 \mathrm{q}$ contains 3 related genes within a 430 -kilobase $(\mathrm{kb})$ region, $I L-1 A, I L-1 B$ and $I L-1 R N$, which encode the pro-inflammatory cytokines IL- $1 \alpha$ and IL-1 $\beta$ as well as their endogenous receptor antagonist IL-1ra respectively ${ }^{5}$. IL-1 $\beta$ is upregulated in the presence of $H$. pylori and is important in initiating and amplifying the inflammatory response to this infection ${ }^{13-15}$. IL-1 $\beta$ is also a potent inhibitor of gastric acid secretion $^{6,7}$; on a molar basis it is estimated to be 100 -fold more potent than proton pump inhibitors and 6,000-fold more potent

Table 1 Estimated haplotype frequencies and linkage disequilibrium coefficients

\begin{tabular}{|c|c|c|c|c|c|c|c|c|c|c|}
\hline \multirow[b]{2}{*}{ Population } & \multirow[b]{2}{*}{ Loci } & \multicolumn{6}{|c|}{ Haplotype $^{*}$} & \multicolumn{3}{|c|}{ Disequilibrium $\dagger$} \\
\hline & & $1-1$ & $1-2$ & $2-1$ & $2-2$ & $1-3,4,5$ & $2-3,4,5$ & $D^{\prime}$ & $\chi^{2}$ & $p$ \\
\hline $\begin{array}{l}\text { GCR controls } \\
(n=100)\end{array}$ & $\begin{array}{c}I L-1 B-31 / / L-1 B-511 \\
I L-1 B-31 / / L-1 B+3954 \\
I L-1 B-31 / / L-1 R N \\
I L-1 B+3954 / / L-1 R N\end{array}$ & $\begin{array}{l}0.610 \\
0.420 \\
0.519 \\
0.495\end{array}$ & $\begin{array}{l}0.010 \\
0.200 \\
0.096 \\
0.295\end{array}$ & $\begin{array}{l}0.005 \\
0.380 \\
0.131 \\
0.155\end{array}$ & $\begin{array}{l}0.375 \\
0.000 \\
0.244 \\
0.045\end{array}$ & $\begin{array}{l}0.005 \\
0.010\end{array}$ & $\begin{array}{l}0.005 \\
0.000\end{array}$ & $\begin{array}{r}0.98 \\
-0.53 \\
0.52 \\
-0.20\end{array}$ & $\begin{array}{r}95.2 \\
27.8 \\
26.6 \\
3.8\end{array}$ & $\begin{array}{l}0.0001 \\
0.0001 \\
0.0001 \\
0.05\end{array}$ \\
\hline $\begin{array}{l}\text { Low acid GCR } \\
(n=45)\end{array}$ & $\begin{array}{c}I L-1 B-31 / / L-1 B-511 \\
I L-1 B-31 / / L-1 B+3954 \\
I L-1 B-31 / / L-1 R N \\
I L-1 B+3954 / / L-1 R N\end{array}$ & $\begin{array}{l}0.422 \\
0.273 \\
0.330 \\
0.408\end{array}$ & $\begin{array}{l}0.000 \\
0.149 \\
0.092 \\
0.425\end{array}$ & $\begin{array}{l}0.022 \\
0.560 \\
0.203 \\
0.125\end{array}$ & $\begin{array}{l}0.556 \\
0.018 \\
0.375 \\
0.042\end{array}$ & $\begin{array}{l}0.000 \\
0.000\end{array}$ & $\begin{array}{l}0.000 \\
0.000\end{array}$ & $\begin{array}{r}0.96 \\
-0.27 \\
0.48 \\
-0.17\end{array}$ & $\begin{array}{r}41.4 \\
3.3 \\
10.5 \\
1.4\end{array}$ & $\begin{array}{l}0.0001 \\
0.07 \\
0.001 \\
0.24\end{array}$ \\
\hline $\begin{array}{l}\text { Normal acid GCR } \\
(n=58)\end{array}$ & $\begin{array}{c}I L-1 B-31 / / L-1 B-511 \\
I L-1 B-31 / / L-1 B+3954 \\
I L-1 B-31 / / L-1 R N \\
I L-1 B+3954 / / L-1 R N\end{array}$ & $\begin{array}{l}0.681 \\
0.527 \\
0.611 \\
0.561\end{array}$ & $\begin{array}{l}0.017 \\
0.171 \\
0.087 \\
0.223\end{array}$ & $\begin{array}{l}0.000 \\
0.275 \\
0.130 \\
0.180\end{array}$ & $\begin{array}{l}0.302 \\
0.027 \\
0.155 \\
0.018\end{array}$ & $\begin{array}{l}0.000 \\
0.017\end{array}$ & $\begin{array}{l}0.017 \\
0.000\end{array}$ & $\begin{array}{r}0.95 \\
-0.20 \\
0.47 \\
-0.25\end{array}$ & $\begin{array}{r}52.1 \\
2.3 \\
12.6 \\
3.6\end{array}$ & $\begin{array}{l}0.0001 \\
0.13 \\
0.0004 \\
0.06\end{array}$ \\
\hline $\begin{array}{l}\text { Gastric cancer controls } \\
(n=429)\end{array}$ & $\begin{array}{c}I L-1 B-31 / / L-1 B-511 \\
I L-1 B-31 / / L-1 B+3954 \\
I L-1 B-31 / / L-1 R N \\
I L-1 B+3954 / / L-1 R N\end{array}$ & $\begin{array}{l}0.699 \\
0.498 \\
0.612 \\
0.525\end{array}$ & $\begin{array}{l}0.002 \\
0.203 \\
0.084 \\
0.214\end{array}$ & $\begin{array}{l}0.000 \\
0.250 \\
0.109 \\
0.196\end{array}$ & $\begin{array}{l}0.298 \\
0.048 \\
0.185 \\
0.056\end{array}$ & $\begin{array}{l}0.005 \\
0.009\end{array}$ & $\begin{array}{l}0.004 \\
0.000\end{array}$ & $\begin{array}{r}1.00 \\
-0.16 \\
0.51 \\
-0.07\end{array}$ & $\begin{array}{r}426.6 \\
11.2 \\
112.6 \\
2.1\end{array}$ & $\begin{array}{l}0.0001 \\
0.0008 \\
0.0001 \\
0.14\end{array}$ \\
\hline $\begin{array}{l}\text { Gastric cancer cases } \\
(n=366)\end{array}$ & $\begin{array}{c}I L-1 B-31 / / L-1 B-511 \\
I L-1 B-31 / / L-1 B+3954 \\
I L-1 B-31 / / L-1 R N \\
I L-1 B+3954 / / L-1 R N\end{array}$ & $\begin{array}{l}0.576 \\
0.418 \\
0.423 \\
0.413\end{array}$ & $\begin{array}{l}0.008 \\
0.166 \\
0.155 \\
0.350\end{array}$ & $\begin{array}{l}0.003 \\
0.352 \\
0.152 \\
0.162\end{array}$ & $\begin{array}{l}0.413 \\
0.063 \\
0.259 \\
0.064\end{array}$ & $\begin{array}{l}0.007 \\
0.007\end{array}$ & $\begin{array}{l}0.004 \\
0.004\end{array}$ & $\begin{array}{r}0.98 \\
-0.19 \\
0.39 \\
-0.17\end{array}$ & $\begin{array}{r}352.4 \\
12.8 \\
54.7 \\
11.0\end{array}$ & $\begin{array}{l}0.0001 \\
0.0003 \\
0.0001 \\
0.0009\end{array}$ \\
\hline
\end{tabular}

Data given for pairs of $I L-1$ loci in gastric cancer relatives (GCR), gastric cancer cases and respective control populations.

${ }^{*}$ For all $I L-1 B$ loci, $C$ is denoted by allele 1 and $T$ is denoted by allele 2 .

$+D^{\prime}=D / D_{\max }$ for association of most common alleles at each locus. 
than $\mathrm{H}_{2}$ antagonists ${ }^{16}$. Three diallelic polymorphisms in $I L-1 B$ have been reported, all representing $\mathrm{C}-\mathrm{T}$ base transitions, at positions $-511,-31$ and +3954 base pairs (bp) from the transcriptional start $\operatorname{site}^{17}$. There are conflicting data regarding the functional effects of these polymorphisms on IL-1 $\beta$ production $^{18,19}$. The $I L-1 R N$ gene has a penta-allelic $86-b p$ tandem repeat (VNTR) in intron 2, of which the less common allele $2\left(I L-1 R N^{\star} 2\right)$ is associated with a wide range of chronic inflammatory and autoimmune conditions ${ }^{17}$. IL- $1 R N^{\star} 2$ is associated with enhanced IL-1 $\beta$ production in vitro ${ }^{19}$, but data regarding its effects on IL-1ra production are contradictory ${ }^{20-22}$.

To determine whether these polymorphisms are important with respect to the different outcomes of $H$. pylori infections, we studied their effects on gastric physiology in healthy subjects. We had previously shown that a cohort of 149 first-degree relatives of gastric cancer patients from the West of Scotland had a high prevalence of hypochlorhydria (defined as a pentagastrin-stimulated peak acid output of less than $15 \mathrm{mmol} \mathrm{h}^{-1}$ ) in association with $H$. pylori infection $^{23}$. Of the 103 (69\%) gastric cancer relatives (GCR) infected with the $H$. pylori, 45 had hypochlorhydria and gastric atrophy and 58 had normal or high acid secretion. One hundred unselected newborns from the West of Scotland were available as population controls. We also had available a case-control study of gastric cancer, based on a population from Warsaw, Poland, in which there were 393 gastric cancer cases and 430 controls with DNA samples ${ }^{24}$. We were thus able to determine whether genotypes that modify IL- $1 \beta$ are associated with low acid secretion and gastric atrophy, and whether these same genotypes increase the risk of gastric cancer. These studies were reviewed and approved by the Institutional Review Boards and Ethics Committees of the US National Cancer Institute, the University of Glasgow Hospitals NHS Trust, and the M. Sklodowska-Curie Memorial Cancer Centre (Warsaw).

In both the Scottish and Polish control populations, the alleles at the individual loci of $I L-1 B$ and $I L-1 R N$ were in Hardy-Weinberg equilibrium, with non-significant $\chi^{2}$ values. There was marked linkage disequilibrium among the loci within the gene cluster (see also ref. 25). Linkage disequilibrium between $I L-1 B-31$ and $I L-1 B-511$ was almost total, with $99.5 \%$ of the inferred haplotypes $(I L-1 B-31 / I L-1 B-511)$ in the combined control groups consisting of either $\mathrm{T}-\mathrm{T}$ or $\mathrm{C}-\mathrm{C}$ (Table 1 ). There was also strong linkage disequilibrium $\left(D^{\prime} \approx 0.5\right)$ between $I L-1 B-31$ and $I L-1 R N$ in both populations. However, the two groups differed with respect to linkage disequilibrium between $I L-1 B-31$ and $I L-1 B+3954$, which was strong in the Scottish population controls but relatively weak $\left(D^{\prime}=-0.16\right)$ in the Polish controls. There was no significant linkage disequilibrium between $I L-1 B+3954$ and $I L-1 R N$ in either control group.

There were no significant differences in genotype frequency for any $I L-1$ marker between the GCR and controls or between the total
H. pylori-infected and uninfected GCR (Table 2). Nevertheless, among the infected GCR, those with low acid secretion had a significantly higher frequency of the pro-inflammatory $I L-1 R N^{\star} 2$ allele and the $\mathrm{T}-\mathrm{T}$ haplotype of $I L-1 B-31$ and $I L-1 B-511$ $(I L-1 B-31 \mathrm{~T} / 1 L-1 B-511 \mathrm{~T})$, as compared with the GCR with normal or high acid secretion. Carriers of the $\mathrm{T}$ allele of $I L-1 B-31(I L-1 B-31 \mathrm{~T}+)$ had an age-adjusted odds ratio of 9.1 (95\% confidence interval (CI), 2.2-37), and there was little difference between the homozygous and heterozygous carriers (Table 2). $I L-1 R N^{\star} 2$ homozygotes $\left(I L-1 R N^{\star} 2 /^{\star} 2\right)$ were also at increased risk of hypochlorhydria, although risk among the $I L-1 R N^{\star} 2$ heterozygotes was not significantly increased (Table 2). In a logistic regression model including both factors, the estimated age-adjusted odds ratios for $I L-1 B-31 \mathrm{~T}+$ and $\left.I L-1 R N^{\star} 2\right)^{\star} 2$ were $7.5(95 \% \mathrm{CI}, 1.8-$ 31 ) and 2.1 (95\% CI, 0.7-6.3), respectively. The $I L-1 B+3954$ genotype was not associated with the risk of hypochlorhydria.

There were similar associations between these alleles and the risk of gastric cancer. Carriers of $I L-1 B-31 \mathrm{~T}$ had an increased gastric cancer risk at an odds ratio of 1.9 (95\% CI, 1.5-2.6), with no significant difference between homozygotes and heterozygotes (Table 3). Moreover, $I L-1 R N^{\star} 2$ was associated with an increased risk in homozygotes but not in heterozygotes (Table 3 ). In a logistic regression model including both of these genotypes, the estimated odds ratios for $I L-1 B-31 \mathrm{~T}+$ and $I L-1 R N^{\star} 2{ }^{*} 2$ were $1.6(95 \% \mathrm{CI}$, $1.2-2.2)$ and $2.9(95 \% C I, 1.9-4.4)$, respectively. $I L-1 B+3954 \mathrm{~T}$ homozygotes seemed to be protected against gastric cancer, although the effect did not reach statistical significance (Table 3 ).

The estimated effects of $I L-1 B-31 \mathrm{~T}+$ and $I L-1 R N^{\star} 2{ }^{\star} 2$ were similar in subgroups of gastric cancer cases defined by age, sex, histological type and anatomical site (data not shown). Furthermore, adjustment for other reported risk factors for gastric cancer, including tobacco and alcohol use, $\mathrm{ABO}$ blood group and family history of gastric cancer, did not substantially alter the estimates (data not shown).

The $I L-1 B-31 \mathrm{~T} / I L-1 R N^{\star} 2$ haplotype imparted a greatly increased risk of gastric cancer, as compared with having no copy of $I L-1 B-31 \mathrm{~T}$ and at least one copy of the other $I L-1 R N$ alleles. Twenty-two per cent of cases (compared with eight per cent of controls) had this haplotype, either in its homozygous form or with $I L-1 B-31 \mathrm{C} / I L-1 R N^{\star} 2$, with an odds ratio of 4.4 (95\% CI, 2.8-6.9). In the absence of $I L-1 B-31 \mathrm{~T}$, homozygous $I L-1 R N^{\star} 2$ was associated with a similarly elevated odds ratio of 5.3 (95\% CI, 1.9-14), although this genotype combination was uncommon because of linkage disequilibrium between the two loci. In contrast, the odds ratio for $I L-1 B-31 \mathrm{~T}+$ with no more than one copy of $I L-1 R N^{\star} 2$ was only 1.7 (95\% CI, 1.2-2.3). Nonetheless, because its effect is observed in both homozygotes and heterozygotes, the $I L-1 B-31 \mathrm{~T}$ allele accounts for a greater proportion of excess gastric cancer cases than the $I L-1 R N^{*} 2$ allele, despite their comparable frequencies. The

Table 2 IL-1 genotype frequencies in gastric cancer relatives (GCR) and controls

\begin{tabular}{|c|c|c|c|c|c|c|}
\hline \multirow[b]{2}{*}{ Locus } & \multicolumn{4}{|c|}{ H. pylori-infected GCR } & \multirow[b]{2}{*}{$\begin{array}{l}\text { Uninvected GCR } \\
\quad(n=46)\end{array}$} & \multirow[b]{2}{*}{$\begin{array}{l}\text { Population controls } \\
\qquad(n=100)\end{array}$} \\
\hline & Genotype & $\begin{array}{l}\text { Low acid } \\
(n=45)\end{array}$ & $\begin{array}{c}\text { Normal acid } \\
\quad(n=58)\end{array}$ & $\begin{array}{l}\text { Odds ratio } \\
(95 \% \mathrm{Cl})^{*}\end{array}$ & & \\
\hline$I L-1 B-31$ & $\begin{array}{l}\mathrm{C} / \mathrm{C} \\
\mathrm{C} / \mathrm{T} \\
\mathrm{T} / \mathrm{T}\end{array}$ & $\begin{array}{r}5 \\
28 \\
12\end{array}$ & $\begin{array}{r}30 \\
21 \\
7\end{array}$ & $\begin{array}{c}1.0 \\
8.1(2.0-33) \\
13.6(2.6-71)\end{array}$ & $\begin{array}{r}23 \\
18 \\
5\end{array}$ & $\begin{array}{l}37 \\
50 \\
13\end{array}$ \\
\hline$I L-1 B-511$ & $\begin{array}{l}\mathrm{C} / \mathrm{C} \\
\mathrm{C} / \mathrm{T} \\
\mathrm{T} / \mathrm{T}\end{array}$ & $\begin{array}{r}5 \\
30 \\
10\end{array}$ & $\begin{array}{r}29 \\
21 \\
8\end{array}$ & $\begin{array}{c}1.0 \\
8.3(2.0-34) \\
11.4(2.2-58)\end{array}$ & $\begin{array}{r}23 \\
18 \\
5\end{array}$ & $\begin{array}{l}36 \\
51 \\
13\end{array}$ \\
\hline$I L-1 B+3954$ & $\begin{array}{l}\mathrm{C} / \mathrm{C} \\
\mathrm{C} / \mathrm{T} \\
\mathrm{T} / \mathrm{T}\end{array}$ & $\begin{array}{r}30 \\
15 \\
0\end{array}$ & $\begin{array}{r}35 \\
23 \\
0\end{array}$ & $\begin{array}{c}1.0 \\
0.8(0.3-1.9)\end{array}$ & $\begin{array}{r}28 \\
15 \\
3\end{array}$ & $\begin{array}{r}67 \\
26 \\
7\end{array}$ \\
\hline IL-1RN & $\begin{array}{c}1 / 1 \\
1 / 2 \\
1 / 3,4,5 \\
2 / 2\end{array}$ & $\begin{array}{r}17 \\
14 \\
0 \\
14\end{array}$ & $\begin{array}{r}35 \\
14 \\
2 \\
7\end{array}$ & $\begin{array}{c}1.0 \\
2.4(0.9-6.2) \\
0 \\
5.6(1.8-17)\end{array}$ & $\begin{array}{r}24 \\
15 \\
0 \\
7\end{array}$ & $\begin{array}{r}42 \\
44 \\
2 \\
12\end{array}$ \\
\hline
\end{tabular}

* Odds ratio for low acid versus normal/high acid, adjusted for age and within-family sampling. Cl, confidence interval. 
fraction of gastric cancer in the population that is attributable to $I L-1 B-31 \mathrm{~T}$ is estimated to be $31 \%$, compared with $18 \%$ for $I L$ $1 R N^{\star} 2$. Their combined population attributable fraction is estimated to be $38 \%$, which represents the fraction of gastric cancer cases that are caused by these $I L-1$ alleles.

The $I L-1 B-31$ polymorphism involves a TATA sequence in the $I L-1 B$ promoter. To investigate the effect of $I L-1 B-31$ variants on the induction of IL-1 $\beta$, we used electrophoretic mobility-shift analysis to assess their DNA-binding activity in vitro. Synthetic allele-specific oligonucleotides representing the polymorphic $I L-1 B-31$ sites were incubated with nuclear protein extracts from non-stimulated human monocytes and monocytes activated by lipopolysaccharide (LPS). LPS stimulation induced a fivefold increase in DNA binding (complex 1 ) on the $I L-1 B-31$ T oligonucleotide (Fig. 1, lanes 1 and 2). In contrast, LPS failed to induce complex 1 formation on the $I L-1 B-31 \mathrm{C}$ oligonucleotide (Fig. 1, lanes 5 and 6). Furthermore, complex 1 formation on radiolabelled $I L-1 B-31 \mathrm{~T}$ was specifically blocked by competition with the unlabelled $I L-1 B-31 \mathrm{~T}$, but not the $I L-1 B-31 \mathrm{C}$, oligonucleotide (Fig. 1, lanes 3 and 4). These results indicate that one or more proteins (presumably transcription factors) in complex 1 may be unable to interact with the C-bearing $I L-1 B-31$ allele to form the transcription initiation complex. In parallel experiments assessing allele-specific oligonucleotides for $I L-1 B-511$, there were no differences in binding activity (data not shown), indicating that the effect of $I L-1 B-511$ may be mediated by linkage disequilibrium with the TATA box polymorphism. On the basis of these results and previously published functional data for $I L-1 R N$, hypochlorhydria and gastric cancer may be associated with alleles of $I L-1 B-31$ and $I L-1 R N$ that enhance IL- $1 \beta$ production.

Here we demonstrate that pro-inflammatory genotypes of the $I L$ 1 loci $\left(I L-1 B-31 \mathrm{~T}+\right.$ and $\left.I L-1 R N^{\star} 2 /^{\star} 2\right)$ increase both the likelihood of a chronic hypochlorhydric response to $H$. pylori infection and the risk of gastric cancer, presumably by altering IL-1 $\beta$ levels in the stomach. While the pro-inflammatory effects of high IL-1 $\beta$ concentrations may facilitate the clearance of $H$. pylori from the gastric mucosa, the concomitant inhibition of acid secretion allows the spread of $H$. pylori-induced inflammation from the antrum to the corpus. This functional inhibition is initially reversible but the progressive destruction of parietal cells eventually leads to irreversible hypochlorhydria. A decreased flow of gastric secretions may therefore heighten mucosal damage by allowing the accumulation of bacterial toxins and by-products of inflammation that would normally be diluted and flushed out. The reactive oxygen and nitrogen oxide species that are derived from inflammation are known mutagens, while hypochlorhydria permits superinfection by other bacteria that enhance the production of highly carcinogenic $N$-nitroso compounds ${ }^{26}$.

H. pylori-induced hypochlorhydria also markedly reduces the levels of vitamin $\mathrm{C}$ in gastric juice ${ }^{27}$, further facilitating the forma-

\begin{tabular}{|c|c|c|c|c|}
\hline Locus & Genotype & $\begin{array}{c}\text { Cases } \\
(n=366)\end{array}$ & $\begin{array}{l}\text { Controls } \\
(n=429)\end{array}$ & $\begin{array}{l}\text { Odds ratio } \\
(95 \% \mathrm{Cl})\end{array}$ \\
\hline$I L-1 B-31$ & $\begin{array}{l}\mathrm{C} / \mathrm{C} \\
\mathrm{C} / \mathrm{T} \\
\mathrm{T} / \mathrm{T}\end{array}$ & $\begin{array}{r}128 \\
172 \\
66\end{array}$ & $\begin{array}{r}219 \\
164 \\
46\end{array}$ & $\begin{array}{c}1.0 \\
1.8(1.3-2.4) \\
2.5(1.6-3.8)\end{array}$ \\
\hline$I L-1 B-511$ & $\begin{array}{l}\mathrm{C} / \mathrm{C} \\
\mathrm{C} / \mathrm{T} \\
\mathrm{T} / \mathrm{T}\end{array}$ & $\begin{array}{r}127 \\
170 \\
69\end{array}$ & $\begin{array}{r}217 \\
166 \\
46\end{array}$ & $\begin{array}{c}1.0 \\
1.8(1.3-2.4) \\
2.6(1.7-3.9)\end{array}$ \\
\hline$I L-1 B+3954$ & $\begin{array}{l}\mathrm{C} / \mathrm{C} \\
\mathrm{C} / \mathrm{T} \\
\mathrm{T} / \mathrm{T}\end{array}$ & $\begin{array}{r}212 \\
140 \\
14\end{array}$ & $\begin{array}{r}242 \\
158 \\
29\end{array}$ & $\begin{array}{c}1.0 \\
1.0(0.8-1.4) \\
0.6(0.3-1.1)\end{array}$ \\
\hline$I L-1 R N$ & $\begin{array}{c}1 / 1 \\
1 / 2 \\
1 / 3,4,5 \\
2 / 2 \\
2 / 5\end{array}$ & $\begin{array}{r}148 \\
117 \\
8 \\
93 \\
0\end{array}$ & $\begin{array}{r}230 \\
152 \\
7 \\
39 \\
1\end{array}$ & $\begin{array}{c}1.0 \\
1.2(0.9-1.6) \\
1.8(0.7-4.8) \\
3.7(2.4-5.7) \\
0\end{array}$ \\
\hline
\end{tabular}

tion of $N$-nitroso compounds. The opportunities for DNA damage caused by this cascade of genotoxic factors are amplified by the increased rate of cell turnover in inflamed mucosa. Therefore, genotypes that enhance IL-1 $\beta$ production may favour the initiation of a set of responses to $H$. pylori that result in hypochlorhydria, corpus atrophy and an increased risk of gastric cancer.

Our findings complement the most widely accepted multi-stage model of gastric carcinogenesis ${ }^{4}$, and provide insights into the etiological role of $H$. pylori. We have shown at least two susceptibility loci in the $I L-1$ gene cluster for gastric cancer and its precursors. The effects of these loci influence an early stage of the disease process and require the presence of $H$. pylori infection. Progression towards cancer is probably influenced by other components of the host genetic constitution acting epistatically, as well as by dietary and other factors in the environment. $I L-1 B-31 \mathrm{~T} / I L-1 R N^{*} 2$ constitutes a pro-inflammatory haplotype that is in strong linkage disequilibrium, at least in Caucasian populations. We speculate that this linkage disequilibrium reflects past selective pressures for or against enhancement of the IL-1 $\beta$ response to environmental challenges. Whereas pro-inflammatory genotypes may be advantageous for the host response to some infections, the vigorous IL- $1 \beta$ production associated with $H$. pylori gastric infection may exacerbate mucosal damage and increase the risk of eventual neoplasia.

\section{Methods}

\section{IL-1 genotyping}

$I L-1 B$ polymorphisms were distinguished by two separate methods, polymerase chain reaction single-strand conformation polymorphism (PCR-SSCP) and $5^{\prime}$ nuclease PCR assays (TaqMan). For PCR-SSCP, 50 ng DNA was amplified in a GeneAmp PCR System 9700 (PE Applied Biosystems), using the primer pairs listed in the Supplementary

Information. Amplification was performed in a volume of $20 \mu \mathrm{l}$, containing $10 \mathrm{mM}$ Tris$\mathrm{HCl} \mathrm{pH} \mathrm{8.3,50} \mathrm{mM} \mathrm{KCl,} 1.5 \mathrm{mM} \mathrm{MgCl}_{2}, 200 \mu \mathrm{M}$ each of dATP, dTTP and dGTP, $100 \mu \mathrm{M}$ dCTP, $1 \mu \mathrm{Ci}$ of $\left[\alpha^{-32} \mathrm{P}\right] \mathrm{dCTP}\left(3,000 \mathrm{Ci} \mathrm{mol}^{-1}\right), 80 \mathrm{ng}$ of each primer and 1 unit of Taq polymerase. The thermocycling conditions were as follows: $94^{\circ} \mathrm{C}$ for $10 \mathrm{~min}$; then 5 cycles of $94^{\circ} \mathrm{C}$ for $30 \mathrm{~s}, 65^{\circ} \mathrm{C}$ for $30 \mathrm{~s}$ and $72^{\circ} \mathrm{C}$ for $30 \mathrm{~s}$; then $30 \mathrm{cycles}$ of $94^{\circ} \mathrm{C}$ for $30 \mathrm{~s}, 60^{\circ} \mathrm{C}$ for $30 \mathrm{~s}$ and $72^{\circ} \mathrm{C}$ for $30 \mathrm{~s}$; then 5 cycles of $94^{\circ} \mathrm{C}$ for $30 \mathrm{~s}, 55^{\circ} \mathrm{C}$ for $30 \mathrm{~s}$ and $72^{\circ} \mathrm{C}$ for $30 \mathrm{~s}$. SSCP analysis of the radiolabelled amplification products was performed as described ${ }^{28}$.

For TaqMan assays, primers (Operon Technologies Inc.) and probes (PE Applied Biosystems) were designed using Primer Express software (PE Applied Biosystems). Probes for the T or C allele were 5'-labelled with either FAM (6-carboxyfluoresceine) or VIC fluorogenic dyes, and 3'-labelled with TAMRA (6-carboxytetramethylrhodamine) quencher. PCR amplification was performed in a volume of $25 \mu \mathrm{l}$ containing $50 \mathrm{ng}$ genomic DNA, $1 \times$ TaqMan Universal Master Mix (PE Applied Biosystems), $200 \mathrm{nM}$ for each probe and $900 \mathrm{nM}$ for primers. Cycling conditions were $50^{\circ} \mathrm{C}$ for $2 \mathrm{~min}, 95^{\circ} \mathrm{C}$ for $10 \mathrm{~min}$, then $40 \mathrm{cycles}$ of $95^{\circ} \mathrm{C}$ for $15 \mathrm{~s}$ and $62^{\circ} \mathrm{C}$ for $1 \mathrm{~min}$, as recommended by the manufacturer. Thermal cycling of optical plates was performed in GeneAmp PCR System 9700 and endpoint analysis was performed in the ABI PRISM 7700 Sequence Detection System (PE Applied Biosystems). Sequences of primers and probes for $I L-1 B$ TaqMan assays are available from the authors.

For $I L-1 R N$, genomic DNA was amplified using PCR under the conditions described above for $I L-1 B$, using forward primer $5 '$-CCCCTCAGCAACACTCC-3' and reverse primer $5^{\prime}$-GGTCAGAAGGGCAGAGA-3'. The PCR products were separated by electrophoresis on $2 \%$ agarose gels and stained with ethidium bromide. Alleles were sized relative to a 1-kb DNA ladder and coded conventionally as follows: allele $1=4$ repeats, allele $2=2$ repeats, allele $3=5$ repeats, allele $4=3$ repeats, allele $5=6$ repeats; the rarer alleles 3, 4 and 5 were grouped in the statistical analysis.

A total of 93\% (366/393) of the gastric cancer cases, 99\% (429/430) of their population controls, and all GCR subjects and their newborn population controls were successfully genotyped for all four loci.

\section{Electrophoretic mobility shift assay (EMSA)}

Nuclear extracts were prepared from freshly isolated human monocytes as described ${ }^{29}$, after no stimulation or addition of $1 \mu \mathrm{g} \mathrm{ml}^{-1}$ LPS derived from E. coli (Sigma) for $30 \mathrm{~min}$. Complementary single-stranded oligonucleotides were synthesized (Life Technologies) as follows (variant nucleotides in bold):

\section{$I L-1 B-31: \quad 5^{\prime}$-TGCTTTTGAAAGCC/TATAAAAACAGCG-3' \\ IL-1B-511: $\quad$ 5' $^{\prime}$-TGACAGAGAGCTCCC/TGAGGCAGAGAAC-3'}

Complementary strands were annealed by combining $2 \mu \mathrm{g}$ of each oligonucleotide and $6 \mu \mathrm{l}$ of $10 \times$ annealing buffer ( $500 \mathrm{mM}$ Tris, $100 \mathrm{mM} \mathrm{MgCl}_{2}$ and $50 \mathrm{mM}$ dithiothreitol) in a $60-\mu \mathrm{l}$ reaction, placing in a boiling water bath for $5 \mathrm{~min}$ and allowing to cool to room temperature. The DNA-protein binding reaction was conducted in a $20-\mu l$ volume containing $7 \mu \mathrm{g}$ of nuclear protein extract, $1 \mu \mathrm{g}$ poly (dI-dC) (Sigma), $4 \mu \mathrm{l}$ of $5 \times$ binding 
buffer (60 mM HEPES, $7.5 \mathrm{mM} \mathrm{MgCl} 2,300 \mathrm{mM} \mathrm{KCl}, 1 \mathrm{mM}$ ethylenediamine-tetraacetic acid, $2.5 \mathrm{mM}$ dithriothreitol, $50 \%$ glycerol and 4-(2-aminoethyl)-benzenesulphonyl fluoride hydrochloride) and $2.5 \times 10^{4}$ c.p.m. of ${ }^{32}$ P-labelled oligonucleotide probe. UNSCAN-IT 5.1 software (Silk Scientific) was used for densitometric analysis of the autoradiographs.

\section{Statistical analysis}

Hardy-Weinberg equilibrium of alleles at individual loci was assessed by $\chi^{2}$ statistics. Haplotype frequencies for pairs of alleles were estimated using the Estimating Haplotypefrequencies (EH) software program (ftp://linkage.rockefeller.edu/software/eh). Linkage disequilibrium coefficients $D^{\prime}=D / D_{\max }$ and $\chi^{2}$ values were calculated for pairs of the most common alleles at each locus using the LINKDOS software program (distributed with GENEPOP, ftp://ftp.cefe.cnrs-mop.fr/pub/PC/MSDOS/GENEPOP/). Odds radios with Cornfield $95 \%$ confidence intervals and logistic regression models controlling for the effects of possible confounders were computed using STATA version 5.0 software (STATA Press). The odds ratios for hypochlorhydria were age-adjusted (categorized as $\leqslant 35,36-$ $45,46-55$ and $>55$ years) because of its age-dependence ${ }^{23}$ and their confidence intervals were based on robust variance estimates ${ }^{30}$ which adjust for within-family correlation, to account for sampling of several members of a given family.

Received 21 October 1999; accepted 4 February 2000.

1. Blaser, M. J. Helicobacter pylori and gastric diseases. Br. Med. J. 316, 1507-1510 (1998)

2. El-Omar, E. et al. Helicobacter pylori infection and abnormalities of acid secretion in patients with duodenal ulcer disease. Gastroenterology 109, 681-691 (1995).

3. El-Omar, E. et al. Helicobacter pylori infectin and chronic gastric acid hyposecretion. Gastroenterology 113, 15-24 (1997).

4. Correa, P. Human gastric carcinogenesis: a multistep and multifactorial process-First American Cancer Society Award Lecture on Cancer Epidemiology and Prevention. Cancer Res. 52, 6735-6740 (1992).

5. Dinarello, C. A. Biologic basis for interleukin-1 in disease. Blood 87, 2095-2147 (1996).

6. Wallace, J. L., Cucala, M., Mugridge, K. \& Parente, L. Secretagogue-specific effects of interleukin-1 on gastric acid secretion. Am. J. Physiol. 261, G559-G564 (1991).

7. Beales, I. L. \& Calam, J. Interleukin 1 beta and tumour necrosis factor alpha inhibit acid secretion in cultured rabbit parietal cells by multiple pathways. Gut 42, 227-234 (1998).

8. Parkin, D. M., Pisani, P. \& Ferlay, J. Estimates of the worldwide incidence of 25 major cancers in 1990 Int. J. Cancer 80, 827-841 (1999).

9. Sipponen, P. Gastric cancer-a long-term consequence of Helicobactor pylori infection? Scand. J. Gastroenterol. 201, (suppl.), 24-27 (1994).

10. Yamaoka, Y. et al. Relationship between Helicobacter pylori iceA, cagA, and vacA status and clinical outcome: studies in four different countries. J. Clin. Microbiol. 37, 2274-2279 (1999).

11. Hansson, L. E. et al. The risk of stomach cancer in patients with gastric or duodenal ulcer disease. $N$. Engl. J. Med. 335, 242-249 (1996).

12. Kuipers, E. J. et al. Atrophic gastritis and Helicobacter pylori infection in patients with reflux esophagitis treated with omeprazole or fundoplication. N. Engl. J. Med. 334, 1018-1022 (1996).

13. Noach, L. A. et al. Mucosal tumor necrosis factor-alpha, interleukin-1 beta, and interleukin-8 production in patients with Helicobacter pylori infection. Scand. J. Gastroenterol. 29, 425-429 (1994).

14. Basso, D. et al. Helicobacter pylori infection enhances mucosal interleukin-1 beta, interleukin-6, and the soluble receptor of interleukin-2. Int. J. Clin. Lab. Res. 26, 207-210 (1996).

15. Jung, H. C., Kim, J. M., Song, I. S. \& Kim, C. Y. Helicobacter pylori induces an array of proinflammatory cytokines in human gastric epithelial cells: quantification of mRNA for interleukin-8, 1 alpha/beta, granulocyte-macrophage colony-stimulating factor, monocyte chemoattractant protein-1 and tumour necrosis factor-alpha. J. Gastroenterol. Hepatol. 12, 473-480 (1997).

16. Wolfe, M. M. \& Nompleggi, D. J. Cytokine inhibition of gastric acid secretion-a little goes a long way. Gastroenterology 102, 2177-2178 (1992).

17. Bidwell, J. L. et al. Cytokine gene polymorphism in human disease: on-line databases. 〈http:// www.pam.bris.ac.uk/services/GAI/cytokine4.htm.)

18. Pociot, F. et al. A TaqI polymorphisms in the human interleukin-1 beta (IL-1 beta) gene correlates with IL-1 beta secretion in vitro. Eur. J. Clin. Invest. 22, 396-402 (1992).

19. Santtila, S., Savinainen, K. \& Hurme, M. Presence of the IL-1RA allele 2 (IL1RN*2) is associated with enhanced IL-1beta production in vitro. Scand. J. Immunol. 47, 195-198 (1998).

20. Andus, T. et al. Imbalance of the interleukin 1 system in colonic mucosa-association with intestinal inflammation and interleukin 1 receptor antagonist genotype 2. Gut 41, 651-657 (1997).

21. Danis, V. A., Millington, M., Hyland, V. J. \& Grennan, D. Cytokine production by normal human monocytes: inter-subject variation and relationship to an IL-1 receptor antagonist (IL-1Ra) gene polymorphism. Clin. Exp. Immunol. 99, 303-310 (1995).

22. Tountas, N. A. et al. Functional and ethnic association of allele 2 of the interleukin-1 receptor antagonist gene in ulcerative colitis. Gastroenterology 117, 806-813 (1999).

23. El-Omar, E. M. et al. Increased prevalence of precancerous changes in relatives of gastric cancer patients: critical role of H. pylori. Gastroenterology 118, 22-30 (2000).

24. Chow, H. W. et al. Risk of stomach cancer in relation to consumption of cigarettes, alcohol, tea and coffee in Warsaw, Poland. Int. J. Cancer 81, 871-876 (1999).

25. Cox, A., Camp, N. J., Nicklin, M. J., Di Giovine, F. S. \& Duff, G. W. An analysis of linkage disequilibrium in the interleukin-1 gene cluster, using a novel grouping method for multiallelic markers. Am. J. Hum. Genet. 62, 1180-1188 (1998).

26. Stockbruegger, R. W. et al. Pernicious anaemia, intragastric bacterial overgrowth, and possible consequences. Scand. J. Gastroenterol. 19, 355-364 (1984).

27. Ruiz, B. et al. Vitamin C concentration in gastric juice before and after anti-Helicobacter pylori treatment. Am. J. Gastroenterol. 89, 533-539 (1994).

28. Carrington, M. et al. Typing of HLA-DQA1 and DQB1 using DNA single-strand conformation polymorphism. Hum. Immunol. 33, 208-212 (1992).

29. Yu, C. R. et al. Differential utilization of Janus kinase-signal transducer activator of transcription signaling pathways in the stimulation of human natural killer cells by IL-2, IL-12, and IFN-alpha. $J$. Immunol. 157, 126-137 (1996).
30. Royall, R. M. Model robust confidence intervals using maximum likelihood estimators. Int. Stat. Rev. 54, 221-226 (1986).

Supplementary information is available on Nature's World-Wide Web site (http:// www.nature.com) or as paper copy from the London editorial office of Nature.

\section{Acknowledgements}

We thank A. Goldstein and N. Chatterjee for advice on genetic and statistical issues, N. Dunlap for technical assistance, D. Gillen for help with subject recruitment and J. Goedert for suggestions. E.M.E. received a European Helicobacter pylori Study Group Research Fellowship from the Digestive Disorders Foundation, UK. This project was partly funded by the National Cancer Institute, National Institutes of Health, USA.

Correspondence and requests for materials should be addressed to E.M.E. (e-mail: elomare@mail.nih.gov). 